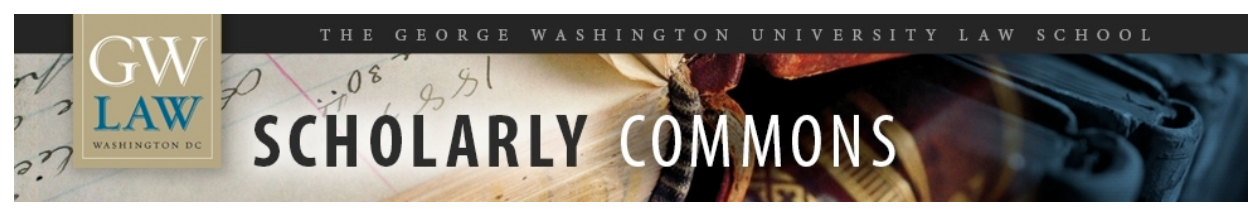

\title{
Informal, Inquisitorial, and Accurate: An Empirical Look at a Problem-Solving Housing Court
}

\author{
Jessica K. Steinberg \\ George Washington University Law School, steinberg@law.gwu.edu
}

Follow this and additional works at: https://scholarship.law.gwu.edu/faculty_publications

Part of the Law Commons

\section{Recommended Citation}

Steinberg, Jessica, Informal, Inquisitorial, and Accurate: An Empirical Look at a Problem-Solving Housing Court (2017). Jessica K. Steinberg, Informal, Inquisitorial, and Accurate: An Empirical Look at a ProblemSolving Housing Court, 42 Law \& Soc. Inquiry 1058 (2017);; GWU Law School Public Law Research Paper No. 2015-48; GWU Legal Studies Research Paper No. 2015-48. Available at SSRN: https://ssrn.com/ abstract=2689006 or http://dx.doi.org/10.2139/ssrn.2689006

This Article is brought to you for free and open access by the Faculty Scholarship at Scholarly Commons. It has been accepted for inclusion in GW Law Faculty Publications \& Other Works by an authorized administrator of Scholarly Commons. For more information, please contact spagel@law.gwu.edu. 


\title{
Informal, Inquisitorial, and Accurate: An Empirical Look at a Problem-Solving Housing Court
}

\author{
Jessica K. Steinberg
}

Substantive justice is often seen as elusive in courts dominated by low-income individuals. Complex court rules, coupled with pervasive lack of counsel, can make it difficult for the traditional adversary process to identify and redress legitimate grievances. This article takes on the social problem of substandard housing and examines whether inquisitorial procedure has the potential to produce accurate outcomes in a tribunal dominated by the unrepresented. Relying on in-court observations of nearly 300 hearings, and a longitudinal review of nearly seventy-five cases, this article surfaces the regularized procedures utilized by a purported "problem-solving" housing court, and theorizes that the inquisitorial features of judicially controlled investigation and enforcement may motivate landlords to repair substantiated housing code violations. This article adds nuance to our understanding of informal justice by identifying the hidden procedural formalisms that may guide alternative decision-making processes. Furthermore, it evaluates the relationship of one iteration of experimental formalism to substantive justice, and suggests that inquisitorial procedures may be correlated with improved accuracy in case outcomes.

\section{INTRODUCTION}

Substantive justice is often seen as elusive in courts dominated by low-income individuals. Complex court rules, compounded by pervasive lack of counsel, can make it difficult for the traditional adversary process to identify and redress legitimate grievances. This article takes on the social problem of substandard housing and examines whether inquisitorial procedure has the potential to produce accurate outcomes in a tribunal dominated by the unrepresented. Relying on data from more than 300 hearings, this article surfaces the regularized procedures utilized by a purported "problem-solving" housing court in the District of Columbia, and theorizes that the inquisitorial features of judicially controlled investigation and enforcement may motivate landlords to repair substantiated housing code violations. This article adds nuance to our understanding of informal justice by identifying the hidden procedural formalisms that may guide alternative decision-making processes and

Jessica K. Steinberg, is an Associate Professor of Clinical Law at George Washington University Law School, jsteinberg@law.gwu.edu. For invaluable feedback on earlier drafts of this article, the author is deeply indebted to Phyllis Goldfarb and Joan Meier, as well as the participants of access to justice conferences hosted by Stanford Law School, U.C. Hastings College of the Law, and the University of Wisconsin School of Law. The author further thanks Samantha Miller, John Rodier, Elyse Schoenfeld, Natasha Baker, and Steven Magnusson for outstanding research assistance. 
evaluates the relationship of one iteration of experimental formalism to substantive fairness.

Low-quality housing stock has plagued poor urban communities for decades (Baker 2013). Particularly in large metropolitan areas, it is not uncommon for residents paying market rate rents to live in units with multiple habitability problems, including rodent infestations, bedbugs, mold, broken locks and windows, inadequate cooking facilities, ineffective waste disposal, faulty electrical wiring, unsafe egress, and cracked doors and walls (Cenziper and Cohen 2008; Reyes and Logan 2014; Smith 2014). In recent years, much attention has been paid to housing quality as a social determinant of health. Studies have connected substandard housing to a wide range of health problems, including chronic illnesses such as asthma and headaches, increased risk of injuries such as burns and falls, malnutrition in children, transmission of infectious disease, anxiety, and depression (Krieger and Higgins 2002; Northridge et al. 2010). When housing quality is poor across a whole neighborhood these effects are exacerbated.

The tenants' rights revolution of the 1970s made reciprocal the tenant's covenant to pay rent and the landlord's covenant to make repairs, and did so by adopting a simple principle: the landlord's right to receive payment was made contingent on maintaining the premises according to the laws of health and safety. The implied warranty of habitability developed both through case law and local ordinances. ${ }^{1}$ It was expected to improve the condition of rental housing stock, reduce hardship for low-income tenants, and cut back on neighborhood blight (Super 2011).

Notwithstanding the enactment of strong protections, it has been difficult for tenants to enforce their rights to decent, safe, and sanity housing in court. In habitability cases - as in all civil matters - courts adhere to a traditional adversarial process. Parties are charged with investigating and presenting their cases and judges remain largely passive with respect to factual development of the claims. Although, in theory, this paradigm may be effective at producing fair outcomes (Fuller 1961), the reality is that low-income parties are typically unrepresented and shunted onto overcrowded dockets, making it difficult to attain substantive justice within an adversarial framework. Thus, tenants often find that repairs and compensation for legitimate claims are out of their reach (Super 2011; Public Justice Center 2015).

The challenges faced by tenants in habitability cases are but one expression of a larger trend in which majority pro se courts are failing to offer access to substantive justice. The trend has been attributed, at least in part, to complex procedures that demand a degree of knowledge and skill that parties who are unrepresented and indigent are unlikely to possess (Steinberg 2015).

In an effort to address the fairness concerns that arise in habitability matters, and by extension, in other civil contexts involving low-income parties, this article offers data and analysis instrumental to evaluating the promise of an alternative procedural regime. The article presents findings from a field study conducted over the course of a two-year period in an experimental Housing Conditions Court (HCC) in the District of Columbia. It focuses, in particular, on classifying the

1. The foundational case, Javins v. First National Realty Corp., 428 F.2d 1071 (D.C. Cir. 1970), was decided by the District of Columbia Court of Appeals. 
court's "informal" procedures as inquisitorial in nature and then examining the effect of an inquisitorial framework on the accuracy of outcomes in the context of substandard housing.

The HCC self-identifies as a problem-solving court but, in fact, adjudicates cases largely in conformance with an inquisitorial regime that departs sharply from traditional adversarial procedure. Inquisitorial procedures are dominant in civil law countries and refer to a system in which the judge controls investigation and fact finding, and the parties' role in producing evidence and enforcing relief is minimized (Langbein 1985; Lerner 2001; Glendon, Carozza, and Picker 2008). As markers of the court's inquisitorial orientation, HCC judges actively examine parties and manage the litigation; independent city-employed housing inspectors are charged with investigating tenant complaints; and the HCC holds episodic hearings, unspooling facts and issues over a period of time, rather than holding a single hearing to determine all issues in the case. The burden to present evidence and legal argument does not fall squarely on the parties in the HCC, but is a responsibility shared with the court. Furthermore, the line that separates the adjudication and enforcement stages of the litigation is fuzzy, with the judge often monitoring the case until repairs are complete instead of closing the matter at the moment liability is established.

Drawing on in-court observations of 327 hearings, and longitudinal case data from seventy-three matters, I offer preliminary evidence that the HCC's inquisitorial procedures have the potential to contribute to accurate outcomes for tenants. I define an "accurate" outcome as one in which a meritorious, or independently verified, claim was resolved favorably. ${ }^{2}$ I was able to determine which tenant claims had merit as an independent housing inspector visited the premises in each case, investigated potential violations, and presented her findings to the court. Specifically, the article sets forth data suggesting that most tenants who bring meritorious cases in the HCC achieve highly favorable outcomes. In addition, the article examines five independent procedural features of the HCC and concludes that its inquisitorial features-independent housing inspections, coupled with regular court hearings before a judge-are most correlated with the court's success. The HCC's use of traditional procedural mechanisms, namely, the filing of formal court papers, settlement negotiations, and the issuance of court orders, appear to be far less associated with accurate case resolutions.

The qualitative and quantitative findings of this article suggest that at least some informal tribunals may not realize their goals through flexible or discretionary decision-making processes, but through formal, and yet alternative, procedural systems. The HCC embodies many typical markers of informal courts: procedural rules are unwritten, discourse in the court is casual, the process is navigable by unrepresented parties, and judges have broad discretion in the way they conduct proceedings. But despite sharing many features with other informal courts, HCC judges do not rely on their discretionary powers to impose ad hoc methods or rules; instead,

2. I engage a particular definition of "accuracy" for purposes of this article, but acknowledge that the term is complex, sometimes subjective, and that a range of legitimate outcomes might be deemed "accurate" (Engler 2013). 
they have devised and then conformed to a procedural regime that is both formalistic and largely inquisitorial in nature. Thus, the HCC is both an informal tribunal and a highly systematized adjudicatory body, although one that bears little in common with the traditional US court. This article makes visible a potential paradox of informal justice by identifying the hidden formalism that can guide these courts' decision-making processes, and submits that further study and evaluation of the procedural systems adopted by other informal tribunals may improve the design of experimental courts more broadly.

Section II of this article situates the Housing Conditions Court within the literature on informal justice, noting that the HCC was developed in the spirit of informalism but can also be studied as an alternative system of formal procedure. Section III of this article describes the purpose and background of the HCC and depicts a typical proceeding, with particular focus on the court's inquisitorial orientation. Section IV evaluates the operation and practices of the HCC as a means of achieving substantive justice and provides data demonstrating that the court has an unusually strong record of accurate outcomes-one that has not often been observed in other tribunals dominated by the unrepresented. Section V unpacks the procedural features driving the HCC's substantive record, and makes the case that the court's deployment of inquisitorial elements is highly correlated to the repair of substandard conditions. Despite limitations inherent to the data set and the methodology, the findings presented in this section suggest that inquisitorial procedure holds promise as a mechanism for improving substantive justice in majority pro se courts.

\section{THE HOUSING CONDITIONS COURT AND INFORMAL JUSTICE}

Courts have experimented with informal tribunals since the late nineteenth century, and a substantial body of literature has evaluated the nature and impact of key informalist movements. These movements include the transformation of the juvenile justice system in the 1880s (Mack 1909; Platt 1969; Rosenheim et al. 2001; Casey 2004), the development and pervasive spread of the small claims system in the 1920s (Yngvesson and Hennesey 1974-1975; O'Barr and Conley 1985), and, most recently, the rise of the problem-solving model in the late 1980s (Nolan 2000; Berman and Feinblatt 2001).

Informal tribunals liberate the adjudication of everyday disputes from formal procedural rules as a means of advancing substantive justice. In her historical analysis of informalist reform movements, Christine Harrington notes that efforts to "delegalize" the court process are typically pursued because "observing procedural rights in the adjudication of minor claims is so prohibitive that formality frustrates the exercise of individual rights and the effective management of conflict by criminal and civil courts." (Harrington 1982, 37).

There is no clear definition of informal justice, but tribunals are often characterized as informal when they adopt procedural norms that are "vague, unwritten, commonsensical, flexible, ad hoc, and particularistic" (Abel 1982a, 2). Whether a tribunal is considered informal may also be a function of whether the legal actors 
involved take "informal or legalistic stances toward the procedural and substantive issues that arise in a case" (Lempert 1989, 347).

Keen observers of informal justice have advanced the theory that informal courts, rather than being "lawless," often adhere to a prescribed set of alternative rules that are developed as a matter of practice and custom. Richard Lempert has argued that "[1]egal rules may in fact structure much of what goes on in informal tribunals for they may specify actions that the tribunals must or may not take, and practical experience may give rise to procedural routines that are honored at least as regularly as the procedures specified in those formal rules that in theory order behavior in regular courts" (1989, 347-48). Richard Abel similarly probes the veneer of informality in many alternative courts, asking: "Are the procedures truly informal or is a new formality insinuated?" (Abel 1982b, 270).

The HCC is an example of the paradoxical nature of informal justice. A casual observer to the HCC would likely classify the forum as informal because its procedures are unwritten and unfamiliar and their execution appears scattershot, discretionary, and improvised. However, upon close study, the HCC has adopted a set of habitual procedural practices that are as observable and norm-bound as those in use in traditional courts. I identify the HCC's "informal" procedures as inquisitorial in nature; however, it is important to note that the inquisitorial orientation of the court is not acknowledged either in the court's authorizing administrative order or by any of the judges or advocates who were instrumental to the creation of the court. That the HCC operates in accordance with regularized procedural norms does not place it outside the ambit of experimentalist informal courts but, rather, deepens our understanding of the exacting-albeit atypical-methods that informal tribunals may rely on in order to resolve disputes.

The judges who launched the HCC express their dispute resolution philosophy as aligned with the problem-solving model of informal justice, in that they are focused on obtaining results and addressing an underlying social problem, rather than on preserving an adversary contest that is agnostic as to outcomes (Berman and Feinblatt 2001). Although the HCC can be accurately characterized as a problem-solving court with regard to its goals, orientation, and some of its methods, ${ }^{3}$ it departs from the general problem-solving rubric in two significant ways. First, in a typical problem-solving court, the defendant must admit guilt or liability to gain access to the alternative proceeding (Mackinem and Higgins 2009; Redlich 2013). In the HCC, however, the court investigates and determines the landlord's liability prior to monitoring repairs. Second, the HCC does not provide the parties with access to an alternative remedy in the way that problemsolving courts offer criminal defendants treatment in place of jail time and fines (Berman and Feinblatt 2003; Wiener and Georges 2013; Wolff 2013). Instead, the HCC offers an alternative process for achieving a substantive remedy that would be available to tenants through traditional proceedings: housing repairs. Because

3. For instance, the quality of the discourse between the judge and the parties in the HCC is representative of informal tribunals more broadly (Lempert 1989), with the judge employing lay terminology, oscillating between tones both stern and encouraging, and typically speaking directly to the parties without the filtering effect of an intermediary. 
the HCC adjudicates liability and enforces traditional remedies, its procedural methods for doing so become particularly salient and relevant to the study of the court.

Although the HCC does not refer to its model as inquisitorial, the combination of judicially controlled investigation and enforcement creates an inquisitorial core at the center of the court's problem-solving mission. This article chooses to examine the HCC as an inquisitorial experiment and seeks to evaluate whether the court's unwritten - and yet consistently applied-procedural system is effective in advancing substantive justice. The findings contribute to our body of knowledge about informal justice, both in dissecting and inverting the concept of "informalism" and also in assessing the efficacy of one iteration of this model in contributing to accurate outcomes.

\section{AN INQUISITORIAL EXPERIMENT: BACKGROUND AND PURPOSE OF THE HOUSING CONDITIONS COURT}

In an effort to offer a meaningful remedy for the social and health issues raised by substandard housing conditions, the Superior Court of the District of Columbia (2010) created the experimental Housing Conditions Court (HCC) through administrative court order (superior court). Support for the establishment of the court was galvanized, at least in part, in response to a seven-part series published by the Washington Post in 2008 on the low-income housing shortage in the District. The series documented many of the egregious habitability issues plaguing the available stock of affordable housing and levied charges of severe mismanagement, and possibly corruption, at the administrative agency charged with enforcing housing repairs (Cenziper and Cohen 2008).

The HCC process works in the following way. Tenants file affirmative suits in the HCC seeking a repair order. The "court" is held once a week for four hours and functions as more of a calendar or docket, where all cases involve the sole issue of housing code violations. The court does not entertain other housing disputes, even related ones, and will not hear a matter if an eviction suit has already been initiated in landlord-tenant court. ${ }^{4}$ Two judges share responsibility for presiding over cases filed in the HCC, one of whom was instrumental in developing the vision for the court. $^{5}$

The judges who administer the HCC have described the court as a "fix-it" court and their primary goal as "getting repairs made." They assert that they want to "solve a social problem" through a simple court process accessible to people without lawyers, rather than tying up parties in formal proceedings. The judges handle disputes in the HCC by relying on their presumptions and instincts about how best to achieve their stated goals. Their practices and procedures have not been codified

4. Conversely, even if an HCC action is filed first, a landlord may proceed with an eviction action. However, the tenant may derive some advantage from the HCC proceedings, as the results of the independent inspection can be utilized to defend against the eviction action in traditional housing court.

5. The judges who preside over the HCC are regular judges within the DC Superior Court system, both of whom have held leadership positions in the civil division. 
or made public in written form, and it is possible they have not been recorded at all. $^{6}$

Before turning to an evaluation of the HCC's procedures in achieving substantive justice, it is first necessary to situate the court in context by determining the procedures, evidentiary rules, and judging philosophies employed, and to note where they depart from traditional principles of adversarial litigation, both in informal and inquisitorial ways. The features of the court are most easily presented through a bird's-eye view of a typical proceeding, which I have drawn from an amalgam of eight weeks of informal observations, sixteen weeks of formal in-court data collection during which 327 hearings were observed, and an in-depth "longitudinal" review of the paper record in seventy-three cases. ${ }^{7}$ This section aims only to offer context for the court's design and describe its processes in depth; analysis of the relationship between the court's procedural features and its case outcomes will be presented in Sections IV and V.

\section{A. An Alternative to Traditional Housing Courts}

The HCC is best understood as an alternative to traditional housing courts, the forum where habitability claims are most often litigated. As context, I offer in this section an overview of the remedies and processes available in typical habitability proceedings, before then turning to the procedural practices that distinguish the HCC.

In the traditional courts, tenants typically have two options for remediating substandard conditions, both of which present challenges. The first option is to withhold rent, provoke the landlord to initiate an eviction suit, and then raise the breach of the implied warranty of habitability as an affirmative defense. The second option is to sue the landlord for violation of the housing code through an affirmative civil action (Bloom 2011). If successful through one of these processes, the substantive law provides substantial relief: tenants may be awarded damages, sanctions, or rent abatements that accrue until the landlord repairs the unsafe conditions. However, the civil courts employ adversarial procedures that render the available remedies very difficult to obtain.

In eviction court, where habitability may be raised as a defense, upward of 98 percent of tenants are unrepresented (Steinberg 2015) and there are not enough city building inspectors available to investigate the thousands of reports of housing code violations (Stringer 2002). Tenants must generate their own evidence and often do so unsuccessfully. For example, a tenant who takes a picture of mildew might learn in court that the judge cannot confirm the blurry black smudge in the photograph as any substance in particular. If unable to prove the substandard

6. A preliminary draft of written HCC procedural rules was developed in 2014, but has yet to be put out for public comment or implemented.

7. I collected the data along with law students who were trained in the study's data collection protocols. For the longitudinal data, I double-checked the completed data sheet against the raw data for the first ten cases, and then subsequently checked 20 percent of the data sheets to ensure uniform coding and to minimize the risk of human error. 
conditions, the tenant will be evicted and the sheriff may arrive within five days to physically remove her belongings from the unit.

Moreover, most tenants facing eviction in traditional courts do not even have the opportunity to appear in front of a judge to make their best case. Upward of 100 landlord-tenant matters may be scheduled in housing court on a daily basis. As a result, judges rely heavily on "hallway negotiations" to remove contested matters from the docket (Engler 2010; Public Justice Center 2015). Many cases are settled between an unrepresented tenant and a landlord's attorney just outside the courthouse doors without any judicial intervention or oversight. While obtaining repairs or damages through an unbalanced negotiation is certainly possible, the prospect of a poor outcome is considerable (New Settlement Apartments' Community Action for Safe Apartments (CASA) and the Community Development Project at the Urban Justice Center 2013). In fact, most tenants in eviction court end up evicted - even though many have valid habitability claims (Bezdek 1992; Super 2011; Public Justice Center 2015). ${ }^{8}$

The tenant who pursues a habitability matter through an affirmative civil action fares no better in the traditional courts. This process is less risky, as no damaging court judgment will result if the tenant loses; however, it is problematic for other reasons. No attorney's fees are awarded in habitability cases, and therefore a lawyer is unlikely to offer representation unless the expected damages are both certain and substantial — which is rare. Apart from rent abatements, the major damages in habitability cases are tied to financial loss, not the severity of the conditions; therefore, even where a family has experienced significant trauma from a condition such as a rodent infestation, it is difficult to recover damages unless work has been missed or doctor's bills have been amassed. Furthermore, losses for personal injurysuch as asthma arising out of a mold condition-are typically recoverable only in tort, meaning that principles such as causation and contributory negligence apply, making damages even more difficult to obtain (Lonegrass 2010). ${ }^{9}$

Compounding matters, affirmative litigation is laden with procedural barriers that make it difficult to proceed without an attorney. Discovery and pretrial motions play a central role in habitability cases, making it unlikely that tenants can succeed without attorney representation. Finally, even in a case that resolves favorably for the tenant, the matter can take up to one or two years to litigate fully, which greatly diminishes the value of any relief obtained. Due to these factors, affirmative habitability cases are not often pursued, leaving many tenants without a meaningful remedy for documented housing code violations (Lazeron 1982; Super 2011; Tillman 2011; Public Justice Center 2015).

As the following sections will demonstrate, the HCC disrupts the traditional adversarial norms found in typical housing courts by placing greater responsibility

8. One possible explanation for the HCC's more favorable outcomes could be that judges take more seriously the habitability claims of tenants who raise violations affirmatively, rather than as a defense to an eviction for nonpayment of rent. It is worth noting, however, that the law indicates that both types of claims should be treated equally.

9. Even this explanation oversimplifies the difficulty of obtaining damages. Although poor housing conditions are known to exacerbate many medical conditions, the tenant's living habits and genetics may be deemed the principal causes of the health disturbance, potentially foreclosing recovery. Further, only a minority of jurisdictions permits the recovery of damages for emotional harm (Lonegrass 2010). 
on the court to assist with claims making, investigate alleged housing code violations, and enforce remedies. Indeed, in the HCC, nearly every aspect of a traditional civil proceedings has been modified to enlarge the role of the judge and diminish party control.

\section{B. Initiating an $\mathrm{HCC}$ Case}

To initiate an action, a tenant must file a written complaint asserting housing code violations and seeking repairs. The court has created a form complaint, and although it is not required, every tenant in the study's longitudinal data set used it. Form complaints are becoming increasingly common as a tool for unrepresented parties, but the HCC form is more fully developed and effective than most. The form elicits factual information to support the two legal elements of a habitability claim: that housing code violations exist, and that the landlord knew about the conditions alleged. The form lists all possible housing code violations in check-thebox format, and also offers several discrete factual assertions a tenant might choose from to support a claim that the landlord knew of the violations. These include, for example, "I left a voicemail for the landlord" and "I spoke directly to the landlord about the conditions." The tenant is responsible for checking the correct boxes and handing the complaint to the clerk.

Although form complaints are typically referred to as nothing more than "self-help," it is worth noting that their use is in keeping with an inquisitorial spirit. Traditionally, parties are responsible for identifying their own legal theories and, in particular, for asserting legally relevant facts. The HCC's form complaint removes the procedural burden of pleading properly and ensures that tenants who appear before the court will have facially valid claims. The court, in essence, develops a skeletal legal claim on behalf of tenants, thus relieving parties of the need to engage in research or communicate with an attorney prior to filing.

\section{Housing Inspections}

Housing inspections are a particularly salient feature of the HCC. The court has a city-employed housing inspector designated for its exclusive use and the judges rely on that inspector to gather key information in each case. The housing inspector visits the premises following the initial hearing and conducts a comprehensive inspection. The inspector looks for any and all housing code violations that exist, and does not focus exclusively on allegations raised in the tenant's complaint. After the inspection, the housing inspector completes a written report documenting her findings in the unit and submits it to the court. Where the inspector has noted violations not alleged by the tenant, the judge will typically incorporate the new issues into the case, in essence amending the complaint sua sponte. The housing inspector appears at every session of the HCC and is available to testify or answer questions about each report. 
Depending on the trajectory of each case, the housing inspector might be asked to return to the unit for reinspections a number of additional times. Ongoing factual disputes about whether repairs have been made, whether repairs are sufficient, or whether repairs are needed at all typically trigger the need for extra housing inspections. The judges place great weight on the housing inspector's findings, often granting automatic credence to the written inspection report.

The investigatory component of the HCC is the bedrock of its inquisitorial model. In traditional proceedings, the parties are solely responsible for amassing evidence and proving their claims in court, which can be both costly and difficult (Langbein 1985; Lerner 2001). A tenant alleging a rodent infestation might be unable to produce physical evidence of the problem, short of hiring a professional extermination crew to document it. The housing inspection process unburdens the parties, to a large degree, of identifying probative, reliable, and trustworthy evidence. Using a trained eye, the inspector might notice claw marks, gnawed electrical cables, and droppings, all of which could suffice as evidence of the infestation. The housing inspector also relieves the tenant of the responsibility to raise all viable claims. Even where the tenant has not alleged a violation, the inspector may independently identify it and incorporate it into the lawsuit.

\section{Evidence and Witnesses}

As further evidence of the HCC's inquisitorial nature, the court provides no explicit opportunity for parties to present their documentary evidence or witnesses. Perhaps as a result, most parties do not attempt to introduce supplementary evidence into the record to corroborate their factual statements. None of the observed hearings involved production of a witness, and less than a fifth involved a party proferring documentary evidence to the judge. Corroborating evidence, apart from that collected during the court's investigation of the case, appears to play a very small role in the judges' decision-making processes.

\section{E. Hearings}

At the initial hearing, the judge actively questions the landlord and tenant about the allegations in the complaint. Neither party is sworn in. The complaint is effectively treated as the tenant's testimony, and the judge typically starts the hearing by asking the landlord to respond to the allegations. The tenant also has an opportunity to speak, but is not required to restate the allegations contained in the complaint. That is, the judge does not use the initial hearing as an opportunity to test the tenant's credibility by comparing the consistency of the allegations in the complaint with the statements made by the tenant in open court. This practice departs quite strikingly from traditional civil practice where parties are required to testify in open court about the factual information underlying particular allegations, pleadings are not regarded as testimony, and close attention is paid to any 
discrepancy between the party's statements in court and prior statements made about the same set of facts out of court.

Following the initial hearing, a number of status hearings are held. In keeping with inquisitorial practices, the judges control examination of the parties on a range of issues, including whether housing code violations exist, whether the landlord or tenant is responsible for fixing the violations, whether the landlord can afford to make the needed repairs, and whether the tenant has hindered access to the unit, thus preventing repairs from being made. Parties offer information in response to the judge's questions and are also provided the opportunity to add information. In the study's sample of more than 300 hearings, landlords had an average representation rate of 41 percent and tenants had an average representation rate of 30 percent. Notably, not a single hearing was observed in which the lawyer performed a direct examination of her client, cross-examined an opponent, or played a substantial role in developing the factual record of the case.

Four unique features of HCC hearings are worth highlighting. First, the HCC does not hold a single evidentiary hearing at which the major issues in the case are resolved. Instead, the judge conducts a series of hearings in each case through which facts and evidence unfold on a rolling basis - a practice common in inquisitorial tribunals but outside the norm in the adversary system (Langbein 1985). At the first hearing, the parties are likely to lodge their allegations with the court; at the next, the results of the inspection report are often entered into the record; at the third hearing, the parties might debate the adequacy of repairs made by the landlord — and so on.

Second, HCC judges are reluctant to make formal findings of fact. In a traditional forum, the judge resolves factual disputes in open court by taking testimony, weighing evidence, and issuing a decision. In keeping with the court's problemsolving spirit, HCC judges typically take a forward-looking approach, either investigating the matter further, or asking the parties to come to a mutually agreeable resolution of the issue. For example, where a landlord disputes that housing code violations exist, the judge is unlikely to pore over the parties' photos, testimony, and documentary evidence, but will dispatch a housing inspector to visit the unit and report back to the court. In a second example, if a landlord complains that he is unable to make repairs because the tenant has changed the locks, the judge will not weigh the landlord's credibility against the tenant's denials in order to determine fault. Rather, the judge will direct the parties to agree that unencumbered access to the unit will be provided at a specific date and time in the near future, and will then schedule a status hearing to monitor the results of that encounter. In both examples, the judge's focus on further developing the record or negotiating an outcome negates the need for a retrospective determination of the facts.

Third, the court manages both the liability and enforcement phases of the litigation. The administrative order giving rise to the HCC states that prevailing tenants are entitled to a repair order. However, during the study period, not a single HCC case was closed at the time a repair order was issued or when liability was otherwise established. Instead, status hearings continue to be scheduled until the judge is satisfied that the landlord has actually resolved all meritorious allegations or the parties stop coming to court. This practice deviates from that of traditional courts, where the case concludes at the moment a judicial order is issued, the 
parties manage enforcement on their own, and a separate action must be initiated to enforce the order where necessary.

Fourth, and relatedly, it is often difficult to determine the moment at which liability is adjudicated in the HCC. The judges' tone and manner with the parties is informal, and the majority of matters do not result in a repair order. Rather, the judges regularly issue ambiguous directives, such as "I'd like to see you get started on these repairs by next Tuesday" or "Call your contractor when you leave court and ask him when he is available to begin work." Directives such as these certainly suggest that the landlord has been found liable. Yet, it is also possible to regard the judge's statements as strong recommendations, or attempts to mediate a dispute, imposing no formal legal duty or obligation. The court relies heavily on these ambiguous directives to influence party behavior. Often, the enforcement phase of the litigation appears to commence-with the judge focusing the parties' attention on when and how repairs will be made-without any clear determination or admission of liability in the record. The informality of this type of direct judge-to-party discourse preserves the problem-solving character of the court, despite its many inquisitorial features.

\section{SUBSTANTIVE JUSTICE IN THE HOUSING CONDITIONS COURT}

This section evaluates case outcomes in the HCC against markers of substantive fairness and concludes that the court has an unusually successful record in producing accurate outcomes. For purposes of this study, an accurate outcome was defined as one in which the landlord took action consistent with the findings of the independent housing inspector. Where the inspector substantiated a tenant's allegations, an accurate outcome would involve repairs. By the same token, when the housing inspector failed to substantiate the tenant's allegations, an accurate outcome would not involve repairs.

The methodology for determining case outcomes was a longitudinal review of court records in seventy-three matters. I analyzed the docket sheet, the tenant's complaint, the notes recorded by the court clerk from each hearing, all housing inspection reports, any repair orders, and any other filing submitted by either party. I coded for a number of variables, among them which conditions were alleged by the tenant; whether the case had a housing inspection and how many inspections were conducted; whether and which housing code violations were documented by the inspector; whether the record contained information on repairs at all, and if so, whether the landlord abated the violations; the type of and reason for the final case disposition; whether a repair order was issued; the length of the case; and the number of hearings held in a case. For each case that was part of the longitudinal study, at least one court hearing was observed in person, with data recorded on numerous procedural and substantive aspects of the proceeding.

In this section, I focus first on an analysis of case merit in the HCC, as the accuracy of an outcome is intimately connected to the strength of the claim. I turn next to substantive outcomes in the cases containing information on whether the 
landlord abated the alleged housing code violations. In this subgroup, representing 62 percent of the total number of cases in the study, definitive conclusions can be drawn about whether favorable outcomes were achieved by tenants. Furthermore, in 85 percent of cases with abatement information, it was possible to conduct a merit assessment, creating a rich pool of data for analysis of the accuracy of outcomes.

Last, this section takes up the cases lacking information on whether the landlord made repairs. In these cases, it is impossible to know whether repairs were ultimately performed, potentially casting doubt on whether substantive fairness was achieved for any of these tenants. However, based on the presence of other case data in these matters, I tentatively conclude that the majority of cases without abatement information involved a tenant who abandoned the litigation at an early stage, rather than a recalcitrant landlord who refused to fix substantiated housing code violations. On the whole, the HCC appears to offer a fair and accurate adjudicatory process not often observed in a court populated by low-income renters.

\section{A. Merit in the HCC: An Analysis of Tenant Allegations and Housing Inspector Findings}

A singular feature in the HCC permits conclusions to be drawn about the merit of the tenant's allegations: the independent housing inspection. In the HCC, a housing inspector is dispatched to render an opinion on housing code violations within the tenant's unit, typically within two to three weeks from the date of the initial hearing. Following the site visit, the inspector files a report in the case indicating whether the tenant's allegations have been substantiated, and also noting any substandard conditions that exist in the unit but were not alleged by the tenant. The housing inspector is a fully institutionalized part of the HCC, not an investigatory device deployed at random or only in selected cases. Housing inspections appear to be scheduled in almost every case that both survives the initial hearing and avoids dismissal for a technical reason. As a result, a rough merit assessment, based on the housing inspector's findings, could be conducted for most tenants' claims.

I evaluated merit in the HCC by comparing the tenant's allegations in the complaint (Figure 1) against the results of the first housing inspection. Allegations substantiated by the housing inspector were deemed meritorious, while allegations that were unsubstantiated by the housing inspector were deemed unmeritorious. This method of assessment was not without drawbacks. To accept the validity of the housing inspector's findings, one must trust that the inspector was both neutral and competent. Furthermore, the potential for undercounting meritorious tenant allegations was a concern. A landlord might remediate some or all legitimate housing code violations in the interval between the initial hearing and the first inspection, leading the housing inspector to record those conditions as unsubstantiated. In addition, in a handful of cases, tenants offered evidence supplementing the housing inspector's findings, and yet this evidence was not considered as "substantiating" for purposes of the merit assessment as it was too difficult to determine its trustworthiness. Notwithstanding these shortcomings, examination of the results of the 


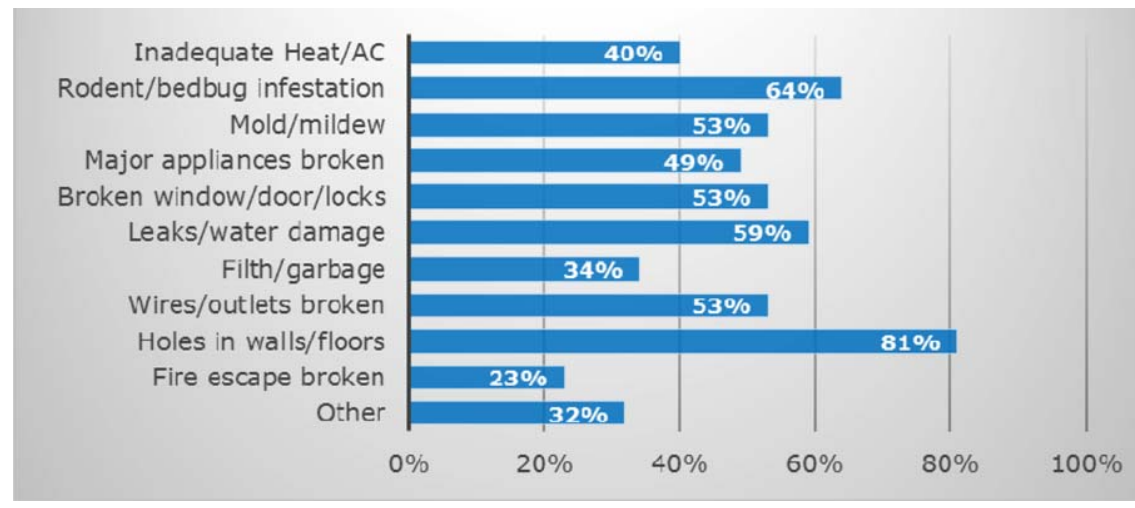

\section{FIGURE 1.}

Type of Tenant Allegations [Color figure can be viewed at wileyonlinelibrary. com]

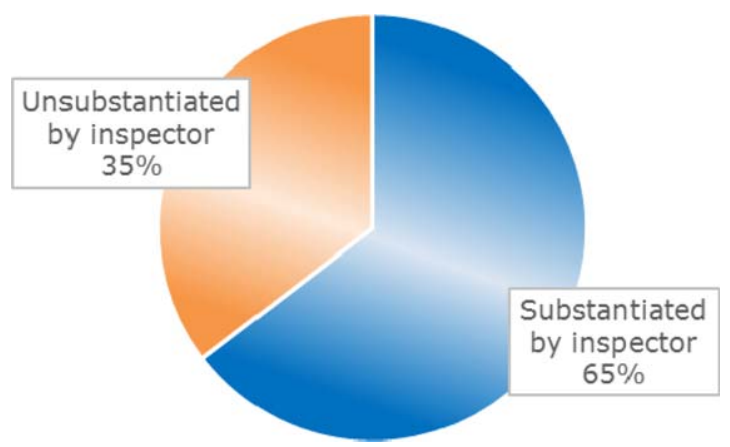

FIGURE 2.

Merit of Tenant Allegations [Color figure can be viewed at wileyonlinelibrary. com]

independent investigation conducted by the housing inspector offered a credible method for determining the approximate merit of tenant claims.

Cases brought in the HCC during the study period were highly meritorious. In the 62 percent of cases that had housing inspections, tenants alleged an average of 5.6 substandard conditions in their complaints, and the housing inspector found an average of 5.5 conditions. These figures do not indicate a near-perfect rate of substantiation, as first appears, but instead offer data on two distinct aspects of the merit determination. The housing inspector substantiated an average of 3.65, or two-thirds, of tenant allegations (Figure 2) but also discovered an average of 1.9 unlawful conditions that the tenant did not allege. That is, not only were most tenant claims corroborated by the housing inspector but, typically, the inspector found evidence of additional violations. Very few cases in the HCC lacked merit entirely. In all but two matters, the housing inspector substantiated at least some of the tenant's allegations. In eleven cases, all of the tenant's allegations were substantiated. 
The merit determination allows for analysis of the HCC's effectiveness on the measure that matters most: substantive justice. Studies that assess substantive case outcomes often look at whether a result is favorable for one party or another, but do not have reliable markers for assessing the fairness or accuracy of the result. The merit of a claim is usually unknown to the observer, and therefore it is impossible to determine what the "right" outcome should have been. Indeterminacy surrounding merit is sometimes regarded as a flaw in studies reporting on case outcomes (Clermont 2009; Engler 2013). Even when a study demonstrates that one class of litigants - tenants, for example-routinely achieves unfavorable outcomes, it can be difficult to ascertain whether the poor outcomes are the result of unmeritorious claims, or are due to more problematic factors, such as lack of representation or structural unfairness within the adjudicatory process.

The inspector's participation in the case permits a determination to be made about the accuracy of an outcome independent of whether the outcome is favorable or unfavorable for a particular party. To illustrate, imagine a case in which the tenant alleges an inoperable stove but the landlord fails to make repairs. Typically, the outcome would be recorded as "unfavorable" for the tenant. However, this study, in relying on inspection data, can evaluate the case outcome by indicia more significant than whether the result is "good" or "bad" for a particular party. If the housing inspector conducts a site visit and confirms the tenant's contention that the stove is broken, a case that concludes without repairs is not just unfavorable but "inaccurate" - the proper result did not materialize. Conversely, if on this same allegation, the housing inspector finds a functioning stove, the landlord's refusal to repair it results in an accurate outcome-even if the tenant experiences it as unfavorable. In this way, the rough merit score assigned by the study in each HCC case provides a gauge for whether the outcome produced a socially desirable result.

\section{B. Case Outcomes for Meritorious Allegations}

More than half the cases in the study sample contained information on both housing inspections and abatements, and I focus first on these, as the strongest statements can be made about results in matters where a merit assessment was conducted and the repair rate was known. That is, for these cases, a fundamental question about substantive justice can be answered: Where the housing inspector confirmed the presence of substandard conditions, did the landlord perform the necessary repairs?

The outcome data for these cases are quite striking, especially as compared to the typical rate of success for tenants in housing court. Looking at meritorious allegations - those substandard conditions alleged by the tenant and substantiated by the housing inspector - the landlord abated 92 percent of housing code violations. To break down that statistic a bit further, the HCC complaint lists forty-one possible housing code violations, which I grouped into eleven categories for purposes of coding. These categories include, among others, broken appliances, inadequate heating or cooling systems, mold and mildew, leaks, infestations, and electrical issues. In every category except one, the landlord abated 100 percent of meritorious allegations. 
In the final category - inadequate heat or air conditioning - the landlord abated twothirds of the alleged and substantiated violations. Significantly, the "accuracy" determination undercounts favorable outcomes for tenants. In an additional 10 percent of cases, landlords repaired alleged conditions before the housing inspector visited the premises, and yet these outcomes were not recorded as "accurate" because the tenant's allegations were never substantiated—although one might surmise the landlord would not have performed repairs had the allegations been frivolous. As a reminder, nearly half the cases in the study pool were missing either housing inspection data or abatement data, or both, and, therefore, less can be said about the court's effectiveness in those matters. Nonetheless, in a full 52 percent of matters in the study sample, nearly all corroborated violations were remedied.

Consider, by contrast, a range of sobering statistics from traditional housing courts around the country: in Philadelphia, 92 percent of tenants in housing court are ultimately evicted; in Kansas City, Missouri, 99.4 percent of housing cases end in eviction; in Hawaii, 97 percent of tenants are evicted; and in Chester, Pennsylvania, 99.2 percent of tenants sued in housing court lose their homes (Blumgart 2015). Often, tenants are evicted even though the likelihood is quite high that substandard housing conditions are present at the unit and would constitute a valid defense to the eviction. In Baltimore, researchers found that 78 percent of surveyed renters "were living amidst serious housing defects" at the time they appeared in court-most involving threats to health or safety, including rat infestations, mold, lack of heat or hot water, or broken refrigerators-but only 8 percent successfully raised a habitability defense (Public Justice Center 2015). David Super (2011) corroborates that successful assertion of the habitability defense is rare, and cites two cities, Cleveland and Detroit, where landlords won victories in upward of 97 percent of nonpayment eviction cases at a time when substandard housing conditions were worsening. The regularity of poor outcomes in traditional housing courts highlights the unusual nature of the HCC's record.

As an additional marker of fairness in the HCC, the abatement rate for unsubstantiated housing code violations was very low. Of the eighty-five allegations tenants made that were unsubstantiated by the inspector, the landlord repaired only 11 percent. Thus, two themes emerge. When a tenant sets forth a meritorious habitability claim, the case is highly likely to result in repairs. Conversely, repairs are highly unlikely to be made in response to an unmeritorious allegation. On both measures, HCC outcomes can be considered accurate, with both tenants and landlords experiencing a just result (Figure 3).

It is worth noting two factors that make the findings on substantive justice in the HCC particularly significant. First, the court's self-appointed enforcement function allows for a deeper understanding of case outcomes than is often available, as the record reflects whether repairs were actually made, rather than whether a paper judgment was issued. In a traditional court, a case typically concludes when the court adjudicates liability and issues an order providing relief to the prevailing party. As a result, data on substantive outcomes are often limited to whether a particular party was awarded a paper judgment; little to no information exists on whether the losing party conformed to the terms set forth in the court order.

The rate of enforcement matters, as a disconnect may exist between the court's records on outcomes and the litigant's recounting of whether the remedy 


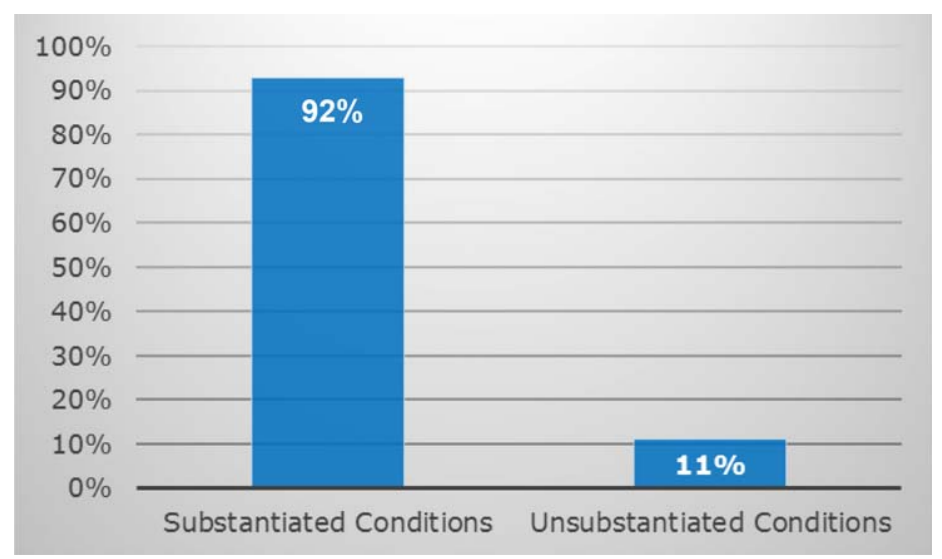

FIGURE 3.

Abatement Rate [Color figure can be viewed at wileyonlinelibrary.com]

sought was obtained. In wage cases, for example, employees who prevail on claims of unpaid overtime or meal breaks often find it difficult to coax courtordered back wages out of noncompliant employers (Dasse 2012). Likewise, in domestic violence proceedings, research suggests that abusers violate the terms of victims' restraining orders with some frequency (Stoever 2014). The HCC's practice is to follow a case to full conclusion-through enforcement-which offers a more meaningful measure of substantive outcomes. The court's unusually high rate of repairs is, therefore, especially consequential. In all cases for which abatement information was available-representing more than half the matters in the study-almost every meritorious claim was resolved favorably, defined not by a judicial declaration of landlord liability but by verified repairs that brought the unit up to code.

Second, the source of information about abatements is typically a highly reliable one-the housing inspector or the tenant-which provides an extra degree of assurance that the repairs noted in the case file were, in fact, performed. In 60 percent of cases with inspection and abatement information, the housing inspector reported on landlord abatements in an official inspection report. In these matters, a final site visit was conducted toward the conclusion of the case, allowing the inspector to confirm that repairs had been made. In 22 percent of cases, the tenant related abatement information to the judge. In only 18 percent of cases was abatement information reported by the landlord, without corroboration from a less self-interested source (Figure 4). Notably, this occurred only when the tenant failed to appear at the final case hearing, and thus the landlord was the only party present to speak to repairs performed at the unit. There were no instances in which final abatement information was recorded on the basis of statements made by the landlord over the tenant's objection. That the HCC's abatement data were largely obtained by reliable sources-whose reports in this context can be trusted-strengthens the finding that accurate outcomes were reached in most cases. 


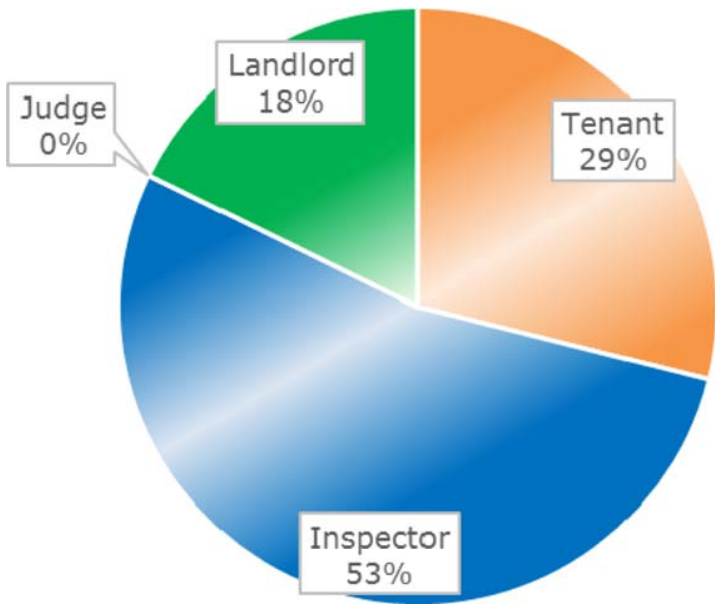

\section{FIGURE 4.}

Source of Abatement Data [Color figure can be viewed at wileyonlinelibrary.com]

Notwithstanding the high repair rate, it is worth examining the length of the adjudicatory process in the HCC to determine whether results must be discounted by the time it takes to achieve them. For matters with housing inspection and abatement data on record, the average length of a case, from complaint to final case disposition, was 147 days, or nearly five months. The average number of hearings in these cases was 5.9. Taking into account all that is accomplished in these matters-the tenant files and serves a complaint, the landlord responds to the allegations in open court, the housing inspector visits the premises at least once, multiple hearings are held before a judge, and the landlord makes repairs-five months is not an unusually lengthy process. Formal adversarial proceedings rarely result in a final judgmentlet alone enforcement of that judgment - in less time (Ostrom and Kauder 1998).

One possible pitfall of the study's data is that substantive outcomes were evaluated at the time of the final case disposition and did not take into account the long-term quality of repairs. A unit might appear to be up to code at the conclusion of the case, only for violations to resurface soon thereafter. This concern is somewhat minimized due to the housing inspector's multiple return visits to the premises, in which half-baked repairs might be discovered and remediated instantly. For instance, in one case, the landlord plugged holes in a tenant's baseboard with vinyl, and at a subsequent hearing, the court ordered the repair to be undone and replaced with sturdier material. Yet it is likely that similar issues might be identified only after the court process is over. For example, a landlord might hire an exterminator once, which keeps the mice at bay for a period, but will not permanently purge the building of them. The data do not indicate whether units remain up to code after the litigation ends.

Furthermore, it is worth reemphasizing that the HCC provides access to a limited remedy-repairs. Tenants cannot recoup financial losses that arise from living with housing code violations, and unless a landlord proves particularly recalcitrant, they are not able to obtain rent abatements either. The HCC is very successful at achieving a modest goal. 


\section{A Caveat to Substantive Justice: What About Cases Without Abatement Information?}

Thus far, this section has covered only cases where information on both housing inspections and abatements was available in the court file. In 38 percent of cases, however, the written record contained no information on whether the landlord abated the housing code violations alleged by the tenant. In this section, I consider the significance of these latter cases in the overall assessment of the court's record of substantive fairness. Although it is impossible to know exactly why abatement information is unavailable in certain case files, and no firm conclusions can be reached regarding the repair rate in these matters, analysis of certain data from each case permits strong inferences to be drawn about substantive outcomes. I conclude that there is good reason not to make the worst-case assumption: that in all, or most, of these matters the tenant set forth meritorious allegations and yet the landlord performed no repairs.

In nearly two-thirds of matters without abatement information, the case terminated at a very early stage in the litigation-before the housing inspector was dispatched. The housing inspector typically visits the premises of any unit that is the subject of a factual or legal dispute in the court, with no triage or case assessment performed by the judge prior to deploying the inspection. Where a case file lacks housing inspection data, it is a strong indication that the case concluded before the parties articulated their dispute in open court. Indeed, the case files for eleven of the eighteen matters confirm that a final case disposition was entered because either the tenant failed to appear at an early hearing or the judge dismissed the action due to a pending eviction matter in landlord-tenant court. In the remainder of matters, no clear data indicate the reason the case was dismissed, but it is reasonable to conclude that the tenant opted, toward the outset of the case, not to prosecute the matter, or was stymied by a procedural requirement (such as service of process) that led to abandonment of the case (Figure 5). This theory is bolstered by the minimal degree of party activity in these matters: the average case length was 37.3 days and an average of 1.7 hearings were held.

If it is burdensome or difficult for tenants to appear in court at all-either due to a procedural hurdle, such as service of process, or because a day of work must be sacrificed to make a court appearance-perhaps initial barriers should be assessed. Nonetheless, the subject of this study is the availability of substantive fairness to tenants who take full advantage of the HCC process. Matters that terminate before the tenant appears in court and communicates her allegations to the judge cannot be counted against the HCC in evaluating its case outcomes. Most cases lacking abatement information appear to fall into this camp.

Importantly, there are ten cases in which housing inspections were conducted, and yet no abatement information was available in the record. These cases-14 percent of the total number of cases in the study-potentially represent the court's failings on accuracy and fairness. In two of these matters, the case concluded pursuant to a settlement agreement that was not filed with the court, and therefore not much is known about the outcomes. In all others, case data strongly indicate that the landlord waged a war of attrition, and with the weapons of delay, inaction, or 


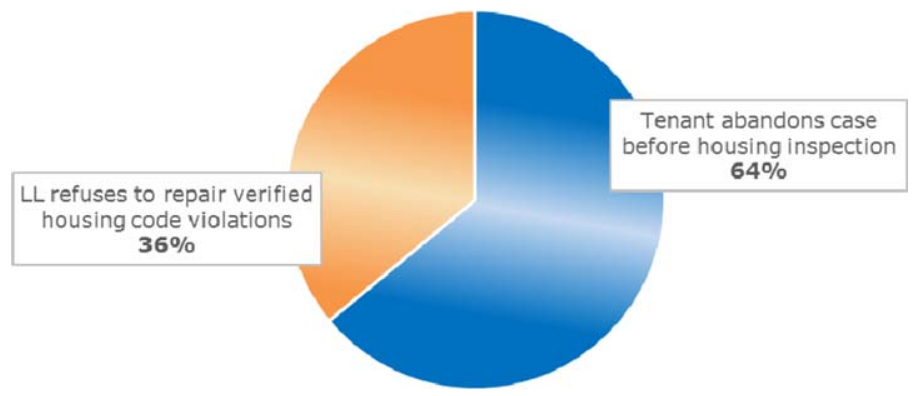

FIGURE 5.

Likely Outcomes for Cases Without Abatement Information [Color figure can be viewed at wileyonlinelibrary.com]

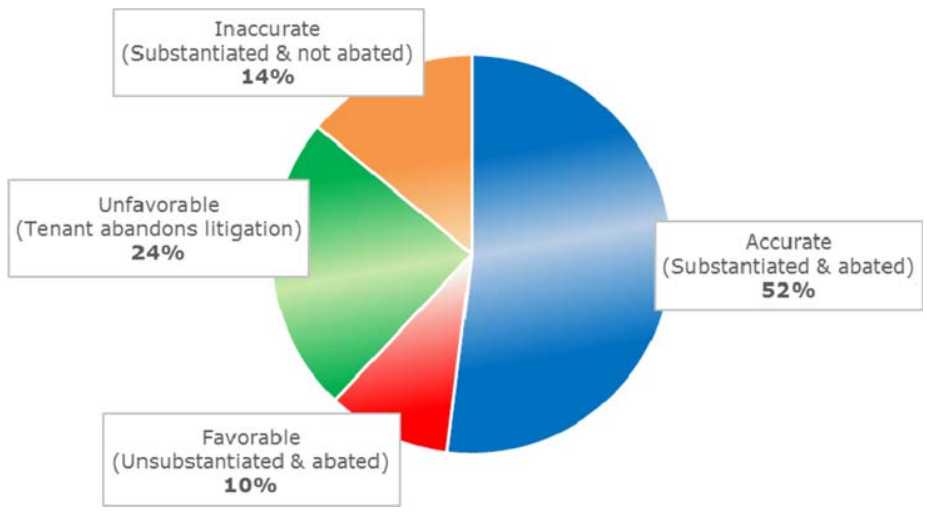

FIGURE 6.

HCC Outcomes [Color figure can be viewed at wileyonlinelibrary.com]

disappearance, was successful in driving the tenant away from court. In these cases, each tenant had meritorious claims and was fully committed to the HCC process. The average case length was 143.3 days, an average of three housing inspections were conducted, and an average of 5.1 hearings were held. Yet, following months of faithful court appearances, the tenants in each matter ultimately stopped coming to court, and the matter was dismissed on that basis.

Nonetheless, the court's overall record is quite good. Even probing the HCC's case outcomes with a skeptic's eye, the least favorable narrative that can be told about the court is this: it achieves accurate outcomes in 52 percent of mattersthose where the landlord's actions mirror the findings of the independent housing inspector. It achieves merely favorable outcomes for an additional 10 percent of tenants whose landlords perform repairs even in the absence of a substantiating housing inspection. It falters slightly, perhaps on markers of procedural access to justice, in the 24 percent of cases involving tenants who file complaints but then abandon their suits early or are prevented from pressing forward with their claims due to a technical reason. And it flops in the 14 percent of cases where tenants allege valid habitability issues, and invest valuable time in the court process, only 
to emerge without improvement to their living conditions (Figure 6). For a housing court, results such as these are unusually positive.

\section{INQUISITORIALISM AND SUBSTANTIVE JUSTICE}

Having described the court's features and substantive record, this section takes up the article's final inquiry: Is there evidence that the HCC's inquisitorial procedures might be responsible for producing its accurate outcomes?

In an adversarial tribunal, housing cases proceed along a familiar trajectory. A lawsuit is filed, the parties engage in out-of-court settlement negotiations, a formal evidentiary hearing is held if negotiations fail, and a judgment is then issued from the bench. By contrast, in the HCC, inquisitorial features such as independent investigation, regular hearings, and active judging are the hallmark procedural components of the court's model. Yet, the court also employs recognizable features drawn from traditional adversary procedure: the plaintiff initiates an action by filing court papers, parties can pursue settlement if they so desire, and the court will, on occasion, issue a formal repair order establishing a landlord's liability. In fact, the only adversarial feature almost entirely lacking is the formal hearing.

To determine whether the court's inquisitorial procedural framework might be responsible for its case outcomes, this section examines five procedural features employed by the court and attempts to delineate which are most correlated with fair results. Three procedural features are traditional to the adversary system: the filing of a complaint, the settlement of cases, and the issuance of judicial orders to award a remedy. Two procedural features are squarely inquisitorial: housing inspections and sequential appearances before a judge. After addressing the traditional procedures, and explaining why they do not appear to be driving the court's substantive results, I set forth evidence that the HCC's inquisitorial procedures do appear to be highly correlated with its fair outcomes. Although correlation is not causation, the analysis in this section suggests that inquisitorial procedure may account for the HCC's superior performance in comparison to sister housing courts.

\section{A. Traditional Adversary Procedures}

To determine whether housing inspections and sequential court hearings are the procedural juggernauts propelling the HCC's results, it is first necessary to set aside the possibility that its case outcomes are the product of traditional procedures. This section demonstrates that very few of the court's substantive outcomes are correlated to the use of traditional procedures. Specifically, the filing of a complaint does not appear to bring about the court's results as, during the study period, only a small fraction of landlords took action to respond to the tenant's allegations before the initial hearing. With regard to settlements and judicial orders-the primary means of resolving disputes in the adversary system-neither procedural mechanism was employed with sufficient frequency in the HCC to explain its overall substantive record. I do not assert in this section that traditional procedures are incapable of producing accurate outcomes, but make the narrower observation that they are 
not strongly correlated with the particular substantive outcomes recorded in the HCC.

\section{Filing of Court Papers}

In both adversarial courts and the HCC, the first step toward litigating a claim involves filing a complaint. In recent years, pleading with factual specificity has become the norm and this practice is adhered to in the HCC (Bell Atl. Corp. v. Twombly 2007; Ashcroft v. Iqbal 2009). Tenants provide facts relevant to each element of a housing conditions claim and, most importantly, allege housing code violations in particular detail. The HCC complaint distinguishes, for example, between cracks and holes in the "ceiling" as opposed to the "walls," and puts landlords on notice of very specific violations, such as a "lack of waterproof floor in the bathroom." Therefore, it is safe to assert that landlords are not simply notified of the existence of housing code violations, but are furnished with very specific information that would make repairs viable immediately upon receipt of the complaint.

There is some evidence that in traditional courts, merely filing a lawsuit can catalyze a defendant to act. ${ }^{10}$ The threat of lengthy litigation, the cost of pretrial discovery, or a belief that a finding of liability is likely may drive a defendant's decision to acquiesce to some or all of plaintiff's demands before litigation begins in earnest. Some defendants may take affirmative action to address allegations set forth in a complaint. For example, a landlord may decide to allow a tenant with a disability to occupy a unit in response to a lawsuit alleging discrimination. Other defendants may respond to a complaint with inaction, creating for the plaintiff a de facto entitlement to the relief requested. In adversarial housing courts, for example, up to 50 percent of tenants fail to respond to a landlord's complaint, resulting in default judgments that are likely to grant the landlord possession of the contested unit as well as damages for unpaid rent (Lawyers' Committee for Better Housing 2003).

In the HCC, neither phenomenon was observed with any great frequency. The filing of a complaint in the HCC was not strongly correlated with either affirmative or passive action on the part of the landlord. In only six cases did the tenant appear at the first hearing and report that the landlord had taken affirmative action to initiate repairs. The vast majority of landlords made no effort to respond to tenant allegations upon receiving the HCC complaint, despite the fact that 98 percent of those later subject to housing inspections were deemed responsible for at least one housing code violation. Furthermore, the filing of HCC complaints did not cause landlords to passively acquiesce to tenant demands. Once service was perfected, every landlord but one entered an appearance in court. Thus, tenants did not typically obtain judicial orders or sanctions on the basis of a landlord's default.

10. A theory of recovery for attorney's fees was, at one time, built around the notion that the plaintiff could claim "prevailing party" status if her lawsuit catalyzed the defendant to act, even if the case was never litigated. Oxford House-A v. City of Univ. City, 87 F.3d 1022 (8th Cir. 1996); Brown v. Local 58, Int'l Bhd. of Elec. Workers, AFL-CIO, 76 F.3d 762 (6th Cir. 1996). 
There are no data that provide an explanation for why the filing of a lawsuit in the HCC appears to have relatively little impact on outcomes. Perhaps the relative ease and low cost of participating in an HCC case disincentivizes landlordseven those who know they are most likely liable-from acting until an inspector officially corroborates the existence of housing code violations. Moreover, the court issues sanctions quite infrequently, and perhaps judicial reticence on this front inadvertently encourages landlords to prolong litigation, rather than defaulting or making immediate repairs. In other words, not only does it cost little to litigate an HCC case, but early resolution of the dispute is unlikely to minimize the landlord's risk or financial exposure, as very few landlords are ultimately subject to monetary sanctions. Regardless of the reason, the upshot is clear: the filing of tenant lawsuits is not substantially correlated to accurate outcomes in the court. The vast majority of tenant allegations are addressed only in the wake of substantial judicial intervention.

\section{Settlements}

Settlement is an important procedural device in an adversarial system. No housing court, or even general jurisdiction civil court, could function if a large percentage of parties opted for trial; the system depends on settlement in the bulk of matters (Clermont 2009). Parties may opt for settlement due to the expense of formal trials or to avoid the immense risk of participating in a winner-takes-all process. It has also been observed that settlements may produce outcomes that benefit both parties, which a court-ordered judgment cannot always achieve (MenkelMeadow 1995). Settlement can be a fair and effective way to resolve disputes, and is the mechanism by which the vast majority of disputes are resolved in the civil justice system (Galanter and Cahill 1994; Menkel-Meadow 1995).

Lending further credibility to the theory that inquisitorial procedure contributes to the court's outcomes, settlements do not appear to be improving the HCC's substantive record in any significant way. Distinct from other formal courts, only 6 percent of cases settled in the HCC. The data do not indicate that settled cases resulted in unfair or unfavorable case outcomes. In fact, in two of the settled cases most or all repairs were made, and in the other two, no information on the abatement rate was available and therefore the accuracy of the outcome is unknown. However, even if settlement offers a viable method for achieving a fair result in the HCC, the low rate of settlement indicates that, as a procedural device, it is not correlated to the vast majority of outcomes. The lion's share of cases were resolved by a judge following numerous court hearings and at least one housing inspection.

It is difficult to know why settlement is so infrequent in the court, especially because there are ample opportunities to settle HCC matters. Parties are often subjected to an hours-long wait before their cases are called and the court has a mediator onsite who can be called on to work with the parties. Furthermore, the typical incentives to settle appear present in the HCC. During the longitudinal study period, 41 percent of landlords were represented, suggesting that indefinite litigation is not entirely cost neutral for a substantial portion of landlords. Last, landlords have access to the information necessary to assess the strength of their opponents' 
case. The housing inspector often visits the premises early in the case, thus putting the landlord on notice of potential liability, much in the same way pretrial discovery might in a traditional court.

Perhaps the low settlement rate can be explained by examining the incentives of tenants. Settlement implies that both parties have made concessions. In HCC cases, however, landlords may not be able to convince tenants to make concessions or settle for lesser repairs. Tenants may feel buoyed by the housing inspector's report, or empowered by seemingly unlimited access to the judge, spurring an eagerness to continue appearing in court until all repairs are complete. Moreover, those landlords who are used to bullying tenants into unfavorable settlements in eviction cases might be low balling offers of settlement in the HCC, unaware that the value of striking a deal has shifted substantially for the tenant.

It is possible that the HCC's low settlement rate may even promote accurate results, although a firm connection is hard to discern. I base this theory on the perception that in systems of mass justice, settlement is more likely to fuel unfair outcomes than in other contexts (Engler 2010). In out-of-court negotiations, the relative status and power of the litigants can have an outsized impact (Grillo 1991). It follows that in housing court-where almost all tenants are unrepresented-settlements can often produce bad faith agreements that function more like default judgments, in which the landlord wins all and the tenant does not benefit from any sort of compromise (New York County Lawyers' Association 2005). In the HCC, 70 percent of tenants are pro se, and 27 percent must litigate their case against a represented landlord. Therefore, it is possible that a low settlement rate may actually be contributing to better case outcomes in the HCC across the board. Certainly, at the very least, the inverse is true: the court's outcomes are not primarily the result of negotiated agreements.

\section{Repair Orders}

In a traditional court, every case that does not settle concludes with the issuance of a judicial order either awarding or denying relief. A favorable court judgment is typically considered a "win" for the prevailing party, regardless of what transpires after the litigation concludes. In the HCC, a "win" was defined differently-not by issuance of an order, but by completion of repairs that the housing inspector deemed necessary. This section considers whether, and to what degree, judicial orders in the HCC might be influencing liable landlords to make repairs.

Like settlements, the rate of repair orders in the HCC was very low. During the study period, only eleven repair orders were issued. In 76 percent of cases involving abatement information, no repair order was on record. Therefore, it is unlikely that repair orders were particularly influential in shaping the court's case outcomes at large.

Notwithstanding the fact that most HCC outcomes cannot be traced to the issuance of a repair order, it is worth considering whether a heavier emphasis on formal orders might benefit the court. In eighty-two percent of cases involving a repair order, the landlord eventually made repairs. Even if the great majority of repairs were performed in the absence of an order, the fact that orders are highly 
correlated with actual repairs seems to suggest it might be a meaningful procedural device. On the flip side, even where judicial orders led to abatements, an average of 146 days and 5.4 hearings elapsed between the order and the repairs, raising questions as to whether the order itself-rather than additional housing inspections and court hearings - was the force driving the landlord to act.

\section{B. Inquisitorial Procedures}

If traditional procedures are not strongly correlated with the HCC's outcomes, then it is reasonable to theorize that the court's use of inquisitorial procedures might explain its results. This section sets forth quantitative and qualitative data suggesting that housing inspections and regular court appearances appear to play a substantial role in influencing landlord behavior.

Landlords appear quite responsive to the housing inspector's findings: when the inspector identifies housing code violations, landlords overwhelmingly make repairs-even when the tenant's complaint does not allege the violations. Qualitative observations of judicial conduct at hundreds of hearings provide examples of how sequential court hearings in the HCC operate to complement the work of the housing inspector. The judges repeatedly advise both parties of their legal obligations, create a formal space for problem solving, and impose a measure of public accountability. This section does not isolate and test the impact of inquisitorial procedures on the court's outcomes, and therefore makes no claim of causation. However, the data herein form the basis of a theory that judicial investigation and management may promote accurate outcomes in a court dominated by the unrepresented.

\section{Housing Inspections}

Independent investigation of the facts is a critical component of inquisitorial procedure, and the housing inspector occupies that role in the HCC. In Section III, I contend that the housing inspector's findings permit a merit determination to be made. That merit determination, in turn, allows the accuracy of an outcome to be established. But, is it also possible that the housing inspector's independent investigation is the procedural mechanism spurring landlord action?

Even a cursory review of the data indicates that housing inspections are facially correlated with outcomes in the court. Eighty-one percent of cases with abatement information involved at least one inspection. Therefore, save a few cases, the inspector visited the premises of most units in which repairs were ultimately made. It is difficult to tease out the impact of the housing inspector on the court's outcomes, as I have defined an accurate result as one in which the housing inspector makes a merit determination regarding the tenant's allegations. All "accurate" outcomes, as defined by this study, necessarily involve a housing inspection.

To probe the influence of the inspector, then, it is useful to examine the abatement rate for housing code violations identified sua sponte by the inspector. In 
most cases, the inspector independently detected at least one violation that was not raised in the tenant's court filing. Earlier, I defined as an "accurate" outcome only those repairs made to conditions that were both alleged by a tenant and substantiated by the housing inspector. In cases where the inspector independently detected the violation, any resulting abatement was not counted as a fair outcome. In fact, one might reasonably assert that such a repair represents an unfair result, as the landlord was not put on notice of the violation via the tenant's complaint. This subsection considers whether the inspector's sua sponte findings are correlated to landlord abatements. If landlords abate violations identified sua sponte, perhaps the decision to repair does, in fact, hinge on the inspector's findings. If, however, landlords do not abate violations identified sua sponte, perhaps the inspector has less impact on a landlord's decision to abate violations than initially seems apparent.

The data here are revealing. Over the course of forty-seven cases, the housing inspector discovered and reported on sixty-three violations not alleged by the tenant. Landlords abated 93 percent of these conditions. Extrapolating from these cases, I posit that the inspector's role may not be merely ancillary in catalyzing outcomes at large, but a principal force.

While these data are suggestive of the housing inspector's central role in prompting landlords to repair housing code violations, alternative explanations exist. It is possible, for instance, that landlords view the housing inspection as the functional equivalent of a judicial determination of liability and are simply acting in accordance with that determination irrespective of who issued it. Certainly, the judges appear to grant the inspection report a great deal of weight. In most hearings observed, the judge relied heavily_often exclusively —on the inspector's findings to guide the next steps in the case. Perhaps, then, landlords would be just as likely to make repairs if housing inspections were eliminated and, instead, HCC judges were tasked with fact finding at formal evidentiary hearings — as traditional adversary procedure would dictate.

There is reason to hypothesize, however, that a substitution of judicial fact finding for housing inspections might not yield equivalent results. In the HCC, the housing inspector performs the fact-finding role actively, through independent investigation, rather than passively, by assembling the assorted facts provided by the parties. This is particularly important in a setting like the HCC where a high number of parties are unrepresented and evidence is difficult to amass. Returning to the rodent infestation as illustration, how might a pro se tenant demonstrate to the court that such a violation exists? It is difficult to collect, transport, and authenticate mouse droppings, and even trickier to record shuffling feet and squeaky movements within walls so that the judge might hear evidence of the infestation. The housing inspector can investigate the tenant's allegations in their natural habitat and report on observations that might not translate well into physical evidence.

Research from adversarial tribunals offers some insight into the comparative advantage of the housing inspector as fact finder. In traditional housing courts, unrepresented tenants often struggle to find and present acceptable or reliable proof that corroborates their allegations (Klein 2010). This can be problematic, as judicial fact finding is driven solely by evidence brought forward by the parties. Judges and researchers have consistently pointed to inadequate evidence as a barrier to fair 


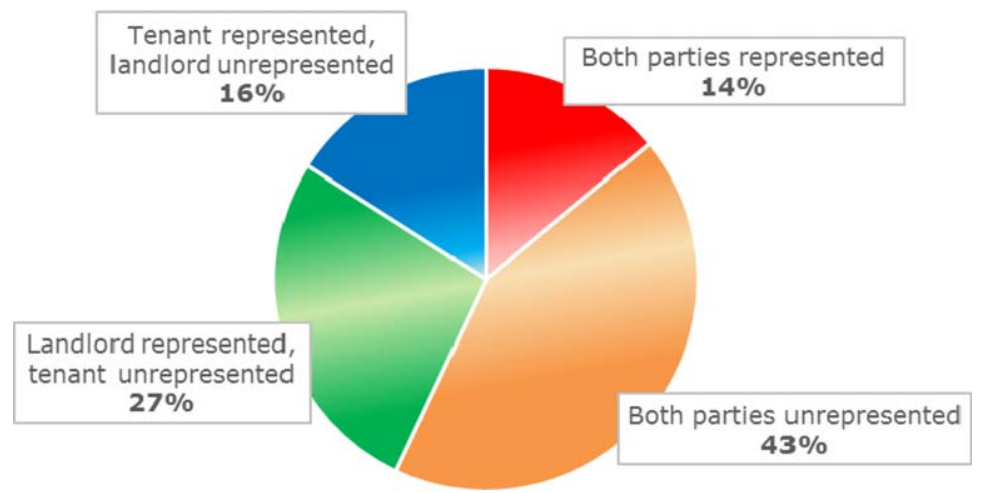

\section{FIGURE 7.}

Rate of Representation in HCC [Color figure can be viewed at wileyonlinelibrary.com]

outcomes, noting that, in the adversary system, the judge must rule against a party who lacks credible proof even when the judge suspects that the party's claim may have merit (Task Force to Expand Access to Civil Legal Services in New York 2010).

The impact of the housing inspector's investigatory role can be seen most plainly when comparing case outcomes of parties with and without representation in both traditional courts and the HCC. In adversarial proceedings-where the parties must produce their own evidence-the unrepresented consistently achieve less favorable outcomes (Seron et al. 2001; Engler 2010; Greiner, Pattanayak, and Hennessy 2013; Steinberg 2015). This is especially true in cases where the landlord has counsel and the tenant does not, as fact finding can skew heavily toward the represented party (New York County Lawyers' Association 2005). By contrast, a wide disparity in outcomes was not observed in the HCC. Seventy-percent of tenants in the HCC were unrepresented during the study period. Further, in 27 percent of cases, the landlord had an attorney while the tenant was pro se (Figure 7). It is typically assumed that cases involving lopsided representation pose the greatest challenge to fairness. However, in HCC cases involving an unrepresented tenant and a represented landlord, tenant claims were substantiated and abated at roughly the same rate as in other cases (Figure 8). ${ }^{11}$ That unrepresented parties who face a represented counterpart fare just as well as the general pool of litigants in the HCC lends powerful support to the notion that the housing inspector's fact finding may correlate to fair outcomes in a way that traditional, adversarial judicial fact finding would not.

\section{Sequential Court Hearings}

The housing inspector appears to play a central part in influencing liable landlords to repair units, and thus in advancing fair and accurate outcomes. However,

11. Of course, it is possible that legal service providers are accepting only the most difficult HCC cases on behalf of tenants, and thus a win rate equivalent to that of pro se tenants does not necessarily demonstrate that lawyers in the HCC forum are unable to obtain more favorable outcomes. 


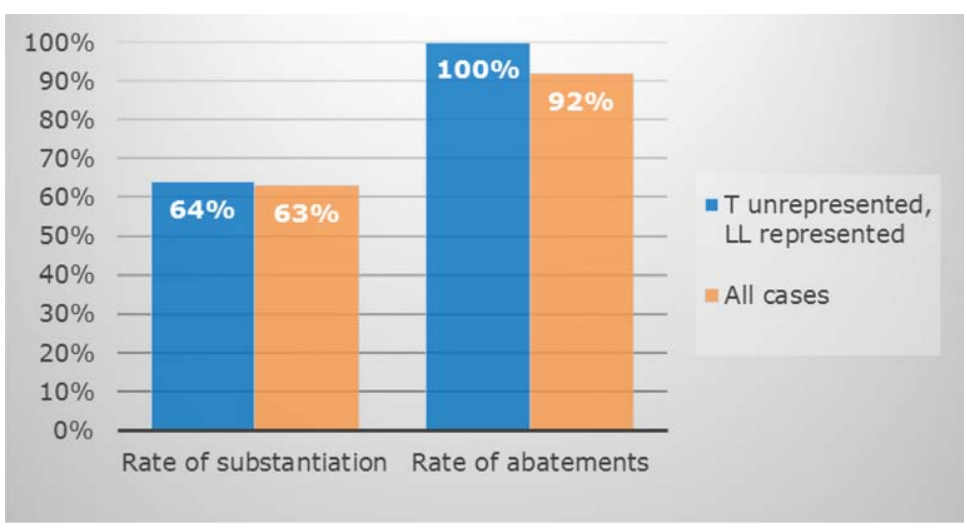

\section{FIGURE 8.}

Lopsided Representation and Outcomes [Color figure can be viewed at wileyonlinelibrary.com]

the housing inspector does not operate in a vacuum and landlords may not be prompted to act on a housing inspector's findings alone. This next subsection considers the impact of a second inquisitorial feature: sequential court hearings before the judge.

A key feature of the $\mathrm{HCC}$ is the requirement that parties return to court for regular hearings until repairs are complete. Although the study produced less evidence of a correlation between sequential hearings and the court's substantive case outcomes than it did with regard to housing inspections, indications of a connection exist. First, the simple fact of judicial oversight might influence landlord behavior. ${ }^{12}$ In 40 percent of cases involving a housing inspection, the landlord had performed all repairs either by the hearing following the inspection, or by the next court hearing, typically three to four weeks later. Perhaps the knowledge that a return to court would be required was sufficient to galvanize landlord action. Second, in most cases, even the 60 percent of landlords who initially failed to make immediate repairs did eventually abate the violations recorded by the inspector. Thus, some feature of the court, in combination with the inspector's visit, must be prompting them to act.

In this section, I focus on the latter subgroup of cases, those in which tenant allegations were substantiated, and yet the landlord was noncompliant, at the outset, in making repairs. In these matters, judges exercised substantial management over the process, scheduling an average of six hearings over a five-month period after the initial housing inspection. At a surface level, regular court hearings are correlated with fair case outcomes: 70 percent of landlords who displayed initial reluctance in performing repairs ultimately remediated all habitability issues on their properties. The quantitative data provide no additional evidence of a link

12. The problem-solving model has been built around the assumption that regular judicial monitoring can greatly influence the behavior of defendants in completing treatment and reducing recidivism (Eaton and Kaufman 2005). 
between court hearings and the repair of housing code violations, but analysis of the study's qualitative data, gleaned from hundreds of in-court observations, offers greater insight into how judicial management in the HCC might influence outcomes.

At hearings that postdate the initial housing inspection, HCC judges performed a variety of functions. They resolved collateral legal and factual disputes, ordered additional housing inspections, mediated the parties' interpersonal disputes, and reprimanded landlords for not making best efforts toward repairs. Consider a number of representative examples. In one matter, a tenant returned to court for a fourth hearing and reported that her substantiated cockroach infestation had not been remedied. The housing inspector had visited the unit more than a month prior, and yet the violation had gone unaddressed. The judge sternly directed the landlord to "do what is necessary to solve [the] problem." By the following hearing, three weeks later, the landlord had begun to install metal barriers to plug up holes through which the vermin were entering the unit. In addition, an exterminator had been hired to attend to the infestation every two weeks.

In a second case, a housing inspection turned up evidence of leaks, broken windows, and nonfunctioning electrical outlets. At the hearing following the inspection, the landlord claimed to have abated all habitability issues. The tenant, however, reported that leaks persisted and the repairs had been ineffective. Moreover, the tenant claimed she had reported the faulty repair to the landlord promptly, but had not received a satisfactory response-an allegation the landlord strenuously denied. The judge sidestepped the dispute, refocusing the parties' attention instead on actions they would take next. The landlord was instructed to order proper materials and come up with a plan for making repairs within two weeks. Six weeks later, all repairs had been performed.

In a third matter, the landlord claimed that the tenant would not permit him to enter the unit in order to make repairs and, also, that she had used her dog to intimidate him. The tenant retorted that the landlord expected unencumbered access to the premises and did not respect her privacy. The judge expressed frustration with both parties. The landlord was instructed to provide twenty-four hours notice prior to entering the tenant's home, and the tenant was instructed to keep her dog restrained. By the following hearing, repairs were in progress.

These are but a few illustrations of judicial management in the HCC drawn from in-court observations. In each case, the judicial actions were quite basic. The judge engaged in basic problem solving, or provided a neutral venue in which the parties could communicate, or simply prodded the landlord to action. Yet, this oversight may well have been effective, as in cases where judges heavily managed recalcitrant landlords, 70 percent ultimately made repairs. At one hearing, the tenant commented to the judge that the landlord only seemed to work on repairs just prior to the next court date. Inspections and regular hearings appear to be a potent procedural combination that might be credited for bringing units up to code in most cases heard in the HCC during the study period. 


\section{CONCLUSION}

Traditionally, the courts have not been a reliable source of relief for tenants with legitimate habitability claims. Yet, in the District of Columbia's Housing Conditions Court-where court-controlled investigation and intensive judicial management are the dominant procedural features-most cases appear to resolve in an accurate manner.

The HCC is unique in four important ways. First, it attempts a meaningful way to bring the legal system to bear on the seemingly intractable social and economic problem of substandard housing. Second, it is one of the few venues housed in a formal trial court system with the explicit goal of serving pro se litigants. Third, the HCC can be viewed both as an informal problem-solving court and also as an alternative system of formal procedure. And last, the court has adopted an inquisitorial procedural framework, marking it as an experimental forum in which traditional adversarial norms do not prevail.

This article provides a rich understanding of the complexities of informal justice, demonstrating that some informal tribunals may not be driven by judicial discretion and procedural flexibility, but by regularized and norm-bound processes that function as an alternative to the traditional adversary system. The HCC's model suggests that accurate case outcomes are achievable in low-income housing cases, and provides some preliminary evidence that inquisitorial procedures may advance substantive justice. Furthermore, this article encourages a closer look at the unwritten procedural methods driving other experimental tribunals. Careful study of the procedures employed by other informal courts may well expose additional de facto systems of formalism and enrich our understanding of the effects of procedural variation on outcomes.

\section{REFERENCES}

Abel, Richard L. 1982a. Introduction. In The Politics of Informal Justice, ed. Richard L. Abel, Vol. 1, 1-13. New York: Academic Press.

- 1982b. The Contradictions of Informal Justice. In The Politics of Informal Justice, ed. Richard L. Abel, Vol. 1, 267-320. New York: Academic Press.

Baker, Kermit. 2013. The Return of Substandard Housing. Housing Perspectives: Research, Trends, and Perspective from the Harvard Joint Center for Housing Studies Blog, February 27. http://housingperspectives.blogspot.com/2013/02/the-return-of-substandard-housing.html (accessed July 22, 2015).

Berman, Greg, and John Feinblatt. 2001. Problem-Solving Courts: A Brief Primer. Law E Policy 23:125-39.

—. 2003. Problem-Solving Justice: A Quiet Revolution. Judicature 4 (86): 182, 213.

Bezdek, Barbara. 1992. Silence in the Court: Participation and Subordination of Poor Tenants' Voices in Legal Process. Hofstra Law Review 20 (3): 533-608.

Bloom, Micki. 2011. Assessing the District's "Fix-It Court." Bread for the City Blog, July 15. http:// www.breadforthecity.org/2011/07/fixitcourt (accessed July 22, 2015).

Blumgart, Jake. 2015. Landlords Have an Edge in Eviction Cases. They Can Afford Lawyers, and Low-Income Renters Can't. Slate Blog, December 8. http://www.slate.com/blogs/moneybox/ 2015/12/08/baltimore_renters_are_losing_their_eviction_cases_because_they_can_t_afford. html (accessed December 9, 2015). 
Casey, Timothy. 2004. When Good Intentions Are Not Enough: Problem-Solving Courts and the Impending Crisis of Legitimacy. Southern Methodist University Law Review 57:14591519.

Cenziper, Debbie, and Sarah Cohen. 2008. Forced Out: A Washington Post Investigation into the Casualties of the District's Real Estate Boom. Washington Post. http://www.washington post.com/wp-srv/metro/forcedout/(accessed July 22, 2015).

Clermont, Kevin M. 2009. Litigation Realities Redux. Notre Dame Law Review 84 (5): 1919-74.

Dasse, Lauren K. 2012. Wage Theft in New York: The Wage Theft Prevention Act as a Counter to an Endemic Problem. CUNY Law Review 16:97-127.

Eaton, Leslie, and Leslie Kaufman. 2005. In Problem-Solving Court, Judges Turn Therapist. New York Times, April 26. http://www.nytimes.com/2005/04/26/nyregion/in-problemsolving-courtjudges-turn-therapist.html?_r=0 (accessed July 22, 2015).

Engler, Russell. 2010. Connecting Self-Representation to Civil Gideon: What Existing Data Reveal About When Counsel Is Most Needed. Fordham Urban Law Journal 37:37-92. - 2013. Turner v. Rogers and the Essential Role of the Courts in Delivering Access to Justice. Harvard Law E Policy Review 7:31-59.

Fuller, Lon. 1961. The Adversary System. In Talks on American Law, ed. Harold J. Berman. New York: Vintage Books.

Galanter, Mark, and Mia Cahill. 1994. Most Cases Settle: Judicial Promotion and Regulation of Settlements. Stanford Law Review 46:1339-90.

Glendon, Mary A., Paolo Carozza, and Colin Picker. 2008. Comparative Legal Traditions in a Nutshell. St. Paul, MN: West Academic Publishing.

Greiner, D. James, Cassandra W. Pattanayak, and Jonathan Hennessy. 2013. The Limits of Unbundled Legal Assistance: A Randomized Study in a Massachusetts District Court and Prospects for the Future. Harvard Law Review 126 (4):901-89.

Grillo, Trina. 1991. The Mediation Alternative: Process Dangers for Women. Yale Law Journal 100:1545-1610.

Harrington, Christine B. 1982. Delegalization Reform Movements: A Historical Analysis. In The Politics of Informal Justice, ed. Richard L. Abel, Vol. 1, 35-71. New York: Academic Press.

Klein, Linda. 2010. Report on the Survey of Judges on the Impact of the Economic Downturn on Representation in the Courts (Preliminary). ABA Coalition for Justice, July 12. http://www. americanbar.org/content/dam/aba/migrated/JusticeCenter/PublicDocuments/CoalitionforJustice SurveyReport.authcheckdam.pdf (accessed July 22, 2015).

Krieger, James, and Donna L. Higgins. 2002. Housing and Health: Time Again for Public Health Action. American Journal of Public Health 92 (5): 758-68.

Langbein, John H. 1985. The German Advantage in Civil Procedure. University of Chicago Law Review. 52 (4): 823-66.

Lawyers' Committee for Better Housing. 2003. No Time for Justice: A Study of Chicago's Eviction Court. http://lcbh.org/sites/default/files/resources/2003-lcbh-chicago-eviction-court-study. pdf (accessed July 22, 2015).

Lazeron, Mark. 1982. In the Halls of Justice, the Only Justice Is in the Halls. In The Politics of Informal Justice, ed. Richard L. Abel, Vol. 1, 119-63. New York: Academic Press.

Lempert, Richard. 1989. The Dynamics of Informal Procedure: The Case of a Public Housing Eviction Board. Law EO Society Review 23 (3): 347-98.

Lerner, Renee L. 2001. The Intersection of Two Systems: An American on Trial for an American Murder in the French Cour D'Assises. University of Illinois Law Review 2001: 791-856.

Lonegrass, Melissa T. 2010. Convergence in Contort: Landlord Liability for Defective Premises in Comparative Perspective. Tulane Law Review 85:413-75.

Mack, Julian. 1909. The Juvenile Court. Harvard Law Review 23:104-22.

Mackinem, Mitchell B., and Paul Higgins. 2009. Adult Drug Courts: A Hope Realized? In Problem-Solving Courts: Justice for the Twenty-First Century? ed. Paul Higgins and Mitchell B. Mackinem, 33-49. Santa Barbara, CA: Praeger. 
Menkel-Meadow, Carrie. 1995. Whose Dispute Is It Anyway?: A Philosophical and Democratic Defense of Settlement (in Some Cases). Georgetown Law Journal 83:2663-96.

New Settlement Apartments' Community Action for Safe Apartments (CASA) and the Community Development Project at the Urban Justice Center. 2013. Tipping the Scales: A Report of Tenant Experiences in Bronx Housing Court. https:/cdp.urbanjustice.org/sites/default/files/ CASA_ES_FINAL.pdf (accessed July 22, 2015).

New York County Lawyers' Association. 2005. The New York City Housing Court in the 21st Century: Can it Better Address The Problems Before It? http://cwtfhc.org/wp-content/ uploads/2009/06/NYCLA_HC_in_21st_Cent.pdf (accessed July 22, 2015).

Nolan, James. 2000. Reinventing Justice: The American Drug Court Movement. Princeton, NJ: Princeton University Press.

Northridge, Jennifer, Olivia F. Ramirez, Jeanette A. Stingone, and Luz Claudio. 2010. The Role of Housing Type and Housing Quality in Urban Children with Asthma. Journal of Urban Health 87 (2): 211-24.

O'Barr, William M., and John M. Conley. 1985. Litigant Satisfaction Versus Legal Adequacy in Small Claims Court Narratives. Law EO Society Review 19:661-99.

Ostrom, Brian J., and Neal B. Kauder, eds. 1998. Examining the Work of State Courts, 1997: A National Perspective from the Court Statistics Project. Bureau of Justice Statistics. http://www. bjs.gov/content/pub/pdf/ewsc97-npcsp.pdf (accessed March 3, 2016).

Platt, Anthony M. 1969. The Child Savers: The Invention of Juvenile Delinquency. New Brunswick, NJ: Rutgers University Press.

Public Justice Center. 2015. Justice Diverted: How Renters Are Processed in the Baltimore City Rent Court. http://www.publicjustice.org/uploads/file/pdf/JUSTICE_DIVERTED_PJC_DEC15. pdf (accessed December 9, 2015).

Redlich, Allison D. 2013. The Past, Present, and Future of Mental Health Courts. In Problem Solving Courts: Social Science and Legal Perspectives, ed. Richard L. Wiener and Eve M. Brank, 147-62. New York: Springer.

Reyes, Emily A., and Tim Logan. 2014. Shortage of Low-Income Housing Pushes Tenants into Dangerous Situations. Los Angeles Times, April 6. http://articles.latimes.com/2014/apr/06/ local/la-me-building-evacuation-20140407 (accessed July 22, 2015).

Rosenheim, Margaret K., Franklin E. Zimring, David S. Tanenhaus, and Bernadine Dohrn, eds. 2001. A Century of Juvenile Justice. Chicago, IL: University of Chicago Press.

Seron, Carroll, Martin Frankel, Gregg Van Ryzin, and Jean Frankel. 2001. The Impact of Legal Counsel on Outcomes for Poor Tenants in New York City's Housing Court: Results of a Randomized Experiment. Law $\mathcal{E}$ Society Review 35 (2): 419-34.

Smith, Greg. 2014. City's “Worst Landlord" Lives in \$1.2M Mansion While Tenants Deal with Rats, Mold, Lead Paint Among Thousands of Violations. New York Daily News, October 11. http://www.nydailynews.com/new-york/worst-landlord-lives-1-2m-mansion-tenants-rats-moldtoxic-paint-article-1.1971278 (accessed July 22, 2015).

Steinberg, Jessica K. 2015. Demand Side Reform in the Poor People's Court. Connecticut Law Review 47:741-807.

Stoever, Jane K. 2014. Enjoining Abuse: The Case for Indefinite Domestic Violence Protection Orders. Vanderbilt Law Review 67 (4): 1015-98.

Stringer, Scott. 2002. Total Collapse: How NYC Department of Buildings' Failed Policies Contributed to Crumbling Buildings. http://assembly.state.ny.us/member_files/067/20021125/ (accessed July 22, 2015).

Super, David A. 2011. The Rise and Fall of the Implied Warranty of Habitability. California Law Review 99:389-461.

Superior Court of the District of Columbia. 2010. Administrative Order 10-07, Housing Conditions Civil Calendar. http://www.dccourts.gov/internet/documents/10-07.pdf (accessed March 13, 2016).

Task Force to Expand Access to Civil Legal Services in New York. 2010. Report to the Chief Judge of the State of New York. https://www.nycourts.gov/accesstojusticecommission/PDF/ CLS-TaskForceREPORT.pdf (accessed July 22, 2015). 


\section{LAW \& SOCIAL INQUIRY}

Tillman, Zoe. 2011. Housing Conditions Calendar Creates a New Forum for Tenants. National Law Journal, July 4. http://www.nationallawjournal.com/id= 1202499203863/Home-courtadvantage-?slreturn $=20160213144708$ (accessed July 22, 2015).

Wiener, Richard L., and Leah Georges. 2013. Social Psychology and Problem-Solving Courts: Judicial Roles and Decision Making. In Problem Solving Courts: Social Science and Legal Perspectives, ed. Richard L. Wiener and Eve M. Brank, 1-22. New York: Springer.

Wolff, Nancy. 2013. Domestic Violence Courts: The Case of Lady Justice Meets the Serpents of the Caduceus. In Problem Solving Courts: Social Science and Legal Perspectives, ed. Richard L. Wiener and Eve M. Brank, 83-112. New York: Springer.

Yngvesson, Barbara, and Patricia Hennessey. 1974-1975. Small Claims, Complex Disputes: A Review of the Small Claims Literature. Law Eु Society Review 9:219-71.

\section{CASES CITED}

Ashcroft v. Iqbal, 556 U.S. 662 (2009).

Bell Atl. Corp. v. Twombly, 550 U.S. 544 (2007).

Brown v. Local 58, Int'l Bhd. of Elec. Workers, AFL-CIO, 76 F.3d 762 (6th Cir. 1996).

Javins v. First Nat'l Realty Corp., 428 F.2d 1071 (D.C. Cir. 1970).

Oxford House-A v. City of Univ. City, 87 F.3d 1022 (8th Cir. 1996). 